Article

\title{
Relative Mass of Brain- and Intestinal Tissue in Juvenile Brown Trout: No Long-Term Effects of Compensatory Growth; with Additional Notes on Emerging Sex-Differences
}

\author{
Joacim Näslund ${ }^{+}(\mathbb{D}$ \\ Department of Biological and Environmental Sciences, University of Gothenburg, Box 463, \\ 40530 Gothenburg, Sweden; joacim.naslund@zoologi.su.se \\ + Current address: Department of Zoology, Stockholm University, Svante Arrhenius väg 18B, \\ 10691 Stockholm, Sweden.
}

Received: 8 August 2018; Accepted: 26 September 2018; Published: 28 September 2018 updates

\begin{abstract}
This study investigated whether compensatory growth causes long-term effects in relative brain- or intestine size in a wild, predominantly anadromous, population of brown trout (Salmo trutta). The subject fish belonged to two treatment groups; one group had undergone starvation and subsequent growth compensation, while the other were unrestricted controls. The main hypothesis that compensatory growth would negatively affect brain and intestinal size, as a consequence of growth trade-offs during the compensatory phase, could not be supported as no significant differences were detected between the treatment groups. Further exploratory analyses suggested that males and females started to diverge in both brain and intestine size at around $130 \mathrm{~mm}$ fork length, with females developing relatively smaller brains and larger intestines. The size at which the differences appear is a typical size for smoltification (saltwater preadaptation), and females tend to smoltify to a higher proportion than males. Smoltification is known to cause a more elongated morphology and relatively smaller heads in salmonids, and the marine lifestyle is associated with rapid growth, which could require relatively larger intestines. Hence, these emerging sex differences could be a consequence of sex-biased smoltification rates. An investigation of wild smolts of both sexes indicated no differences in brain or intestine mass between male and female smolts.
\end{abstract}

Keywords: brain size; intestine size; salmonidae; ontogeny; growth allocation; smoltification

\section{Introduction}

Given a finite supply of energy, different body parts must compete for the resources required to grow [1]. Restricting the energy supply will likely lead to prioritization of maintenance and growth of certain tissues above others. Furthermore, when energy subsequently becomes readily available again, the bodies in growing organisms typically undergo faster-than-normal compensatory growth [2-4]. Faster growth has also been shown to involve prioritization of certain tissues and structures over others, and to be associated with developmental abnormalities [5-7]. Comparative analyses of the size of different organs therefore give insights into differential energy investment into different tissues, which in turn can provide clues to evolutionary and ontogenetic trade-offs $[8,9]$.

The expensive-tissue hypothesis has been put forward as a potential explanation for the exceptional increase in brain size in the human evolutionary lineage, where the increased energetic investment in brain tissue is balanced through a reduced investment in the gut [9]. In relation to their size, both the brain and the gut consume large amounts of energy compared to many other tissues and are thus rightly labelled as metabolically expensive tissues [9-13]. The specific expensive-tissue 
hypothesis concerning a trade-off between the brain and the gut has acquired mixed support when it has been tested in different groups of vertebrates [14-19]. More components may be involved in the trade-offs as suggested by the "energy trade-off hypothesis", a combination of the expensive-tissue hypothesis and general energy balance theory [20], incorporating other energy demanding processes such as locomotion and reproduction [21].

Recent research on fish indicates that there may indeed be trade-offs between the brain and the intestine. More specifically, when guppies (Poecilia reticulata Peters, 1859) were selected for larger and smaller than average brain size, the large-brained fish developed guts with relatively lower wet mass and also produced fewer offspring in their first parturition [15]. In fish, relative brain and intestinal size are not only determined by genetic background, but also by environmental factors and somatic growth rate [22-30], and could thus be suitable for investigating energy allocation trade-offs over the life of fish.

In this study, I investigate the size of the brain and the intestine in wild brown trout (Salmo trutta L.) juveniles, which were subjected to either starvation with subsequent compensatory growth or normal growth. The starvation treatment was applied approximately one year prior to the final sampling [31]. The selection of variables to be measured for this study was based on the expensive-tissue hypothesis, which suggests a trade-off between brain and intestinal tissues [9].

The primary objective of this study was to investigate the long-term effects of previous starvation and subsequent compensatory growth on the relative mass of the brain and intestine. I predicted that the brain size would be smaller in the growth compensating fish, as compared to non-starved controls, due to differential allocation between somatic and neural tissue. With respect to intestine mass in compensating fish, I predicted either a lower relative mass, in case there was a general trade-off between expensive tissues and bodily growth, or a higher relative mass, in case there was compensatory growth of intestines to allow for a higher food processing capacity in compensating fish. I also predicted a general trade-off between the brain and intestine with relatively larger brains being associated with relatively smaller intestines. Furthermore, exploratory analyses of brain and intestine mass were conducted to investigate effects of sex on the ontogeny of brain size development. Sex has previously been shown to contribute to the explained variance in brain size and the size of different brain regions in several fish species [29,32-35], including adult brown trout [36].

Finally, due to the patterns emerging in the analyses of the sex-differences, where the sexes started to diverge at larger sizes (approximately $130 \mathrm{~mm}$ ), I hypothesised that the differentiation may be related to smoltification. Smoltification, where the trout pre-adapts to a life in a marine environment, is partially sex-dependent. Most females smoltify, however a significant proportion of males do not and instead stay in their nursery stream as small-sized resident fish. Smoltification-status could not be reliably determined from the frozen specimens of the original sampling (see Section 4.1.3), so additional samples of smoltifying fish (as determined by body silvering [37]) were obtained for this purpose. In the case that sex differences are general (i.e., in contrast to the hypothesis), sex differences should also be detectable in the fish undergoing smoltification. Stream resident fish were not sampled to conserve the relatively small number of the stream resident fish in the sampled streams.

\section{Results}

\subsection{Body Size at Sampling}

No significant differences between treatments or sexes were found in fork length at sampling (Treatment: $F_{1,89}=0.21, p=0.65$; Sex: $F_{1,89}=0.01, p=0.91$; Treatment $\times$ Sex: $F_{1,89}=0.02, p=0.89$; Figure 1; also see [31,38]). 


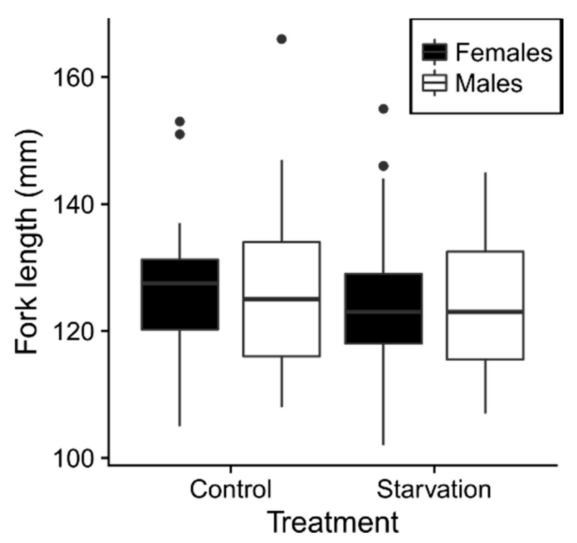

Figure 1. Tukey boxplots showing the distribution of fork length in recaptured fish of different sex from the different treatments. Boxes contain the second and third quartile of the data, separated by the median (horizontal line). Whiskers show the main spread of the data, and dots outside of the whiskers show data points $>1.5$ box-height away from the box.

\subsection{Effects of Compensatory Growth on Brain and Intestine Mass}

Overall, after controlling for fork length, no significant effects of growth compensation were found on either brain dry mass (Length: $F_{1,86}=126.58, p<0.001$; Treatment: $F_{1,86}=2.13, p=0.15$; Figure 2A) or intestine dry mass (Length: $F_{1,88}=68.34, p<0.001$; Treatment: $F_{1,86}=0.77, p=0.38$; Figure 2B).

The relative mass of the brain, as compared to the intestine, (i.e., the brain-intestine-index, BII; see Materials and Methods) generally decreased with increasing body size (Length: $F_{1,86}=23.11$, $p<0.001$; Figure 2C), indicating differential allometric growth for the brain and intestine, where the intestine becomes larger relative to the brain. No significant effects of growth compensation were found when analysing BII (Treatment: $F_{1,86}=0.13, p=0.72$; Figure 2C).
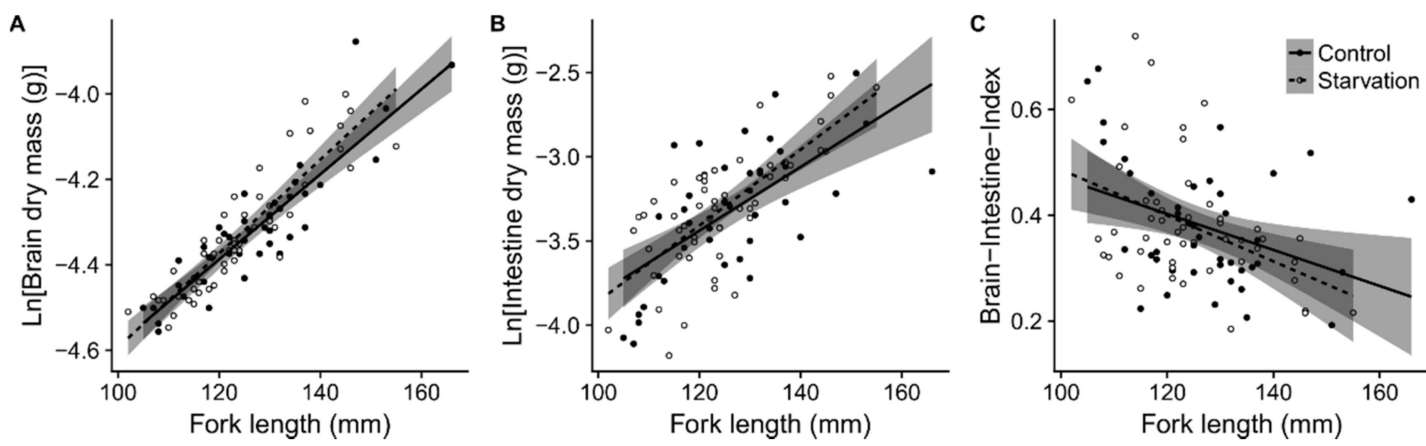

Figure 2. Predicted effects of previous feeding treatment (and subsequent compensatory growth in the "Restricted" group) on (A) brain dry mass, (B) intestine dry mass, and (C) brain-intestine-index. None of the treatment effects were statistically significant. Linear regression lines are based on raw data and are shown along with 95\% confidence bands which are shaded in grey.

\subsection{Effects of Sex on Relative Brain- and Intestine Mass and Head Length}

Male brown trout had a larger relative brain size than females, however only in the larger size range as judged from the differences in slopes for the sexes in the linear model (Length $\times$ Sex interaction: $F_{1,86}=6.36, p=0.013$; Table 1). This effect was confirmed by non-linear local regression (LOESS; Figure 3A), which revealed that males start to diverge from females at a size around $130 \mathrm{~mm}$. The reverse pattern was found for the intestine, with females developing larger intestines at a larger size, relative to males (Length $\times$ Sex interaction: $F_{1,88}=6.61, p=0.012$; Table 2; LOESS: Figure 3B).

The analysis of BII confirmed the patterns that were seen in the individual analyses of brain and intestine dry mass, with the sexes beginning to diverge first at a larger body size (Figure 3C). Changes in brain versus intestine size are most apparent in females, as the BII is conspicuously negative 
in relation to body size for females, while it is less related to size in males (Length $\times$ Sex interaction: $F_{1,86}=7.07, p=0.009$; Table 3, Figure 3C).

The statistical analysis of head length did not reveal a significant interaction effect between fork length and sex (Length $\times$ Sex interaction: $F_{1,89}=1.93, p=0.17$ ). However, plotting head length against fork length revealed a similar pattern as for the brain size when looking at the LOESS, albeit with slightly overlapping 95\% confidence limits at the larger body sizes where the differences were expected (Figure 3D).
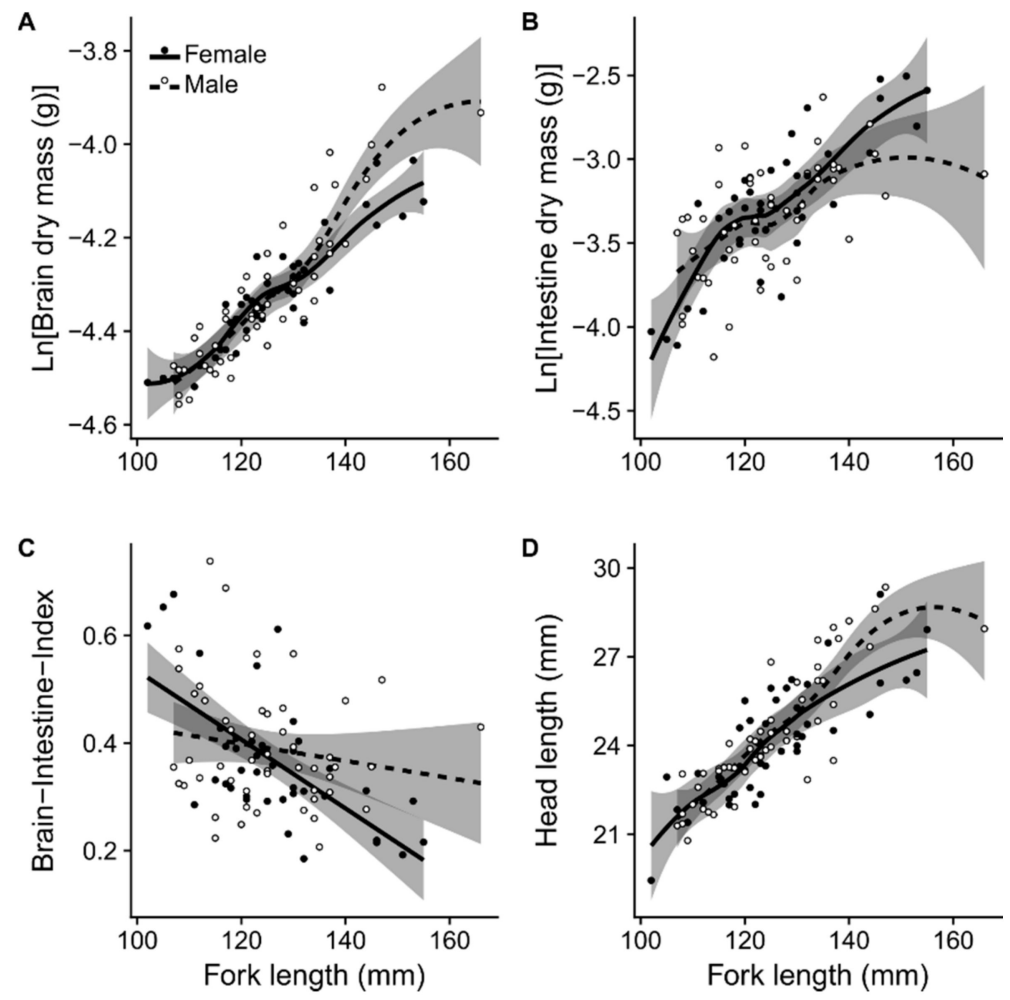

Figure 3. Effects of sex on (A) brain dry mass, (B) intestine dry mass, (C) brain-intestine-index, (D) head length, all in relation to fork length. Lines are based on local regression (LOESS) in (A,B,D), and on linear regression in (C). Grey-shaded areas around regression lines show the 95\% confidence limits.

Table 1. Parameter estimates from the linear model of brain dry mass, with statistical summary. $\mathrm{SE}=$ standard error.

\begin{tabular}{ccccc}
\hline & Estimate & SE & $t$-Value & $p$-Value \\
\hline Intercept & -5.4702 & 0.1023 & -53.46 & $<0.0001$ \\
Length & 0.0090 & 0.0008 & 11.25 & $<0.0001$ \\
Sex (Male) & -0.3300 & 0.1368 & -2.41 & 0.018 \\
Treatment (Starved) & 0.0194 & 0.0133 & 1.45 & 0.149 \\
Length $\times$ Sex (Male) & 0.0027 & 0.0011 & 2.52 & 0.014 \\
\hline
\end{tabular}

Table 2. Parameter estimates from the linear model of intestine dry mass, with statistical summary. $\mathrm{SE}=$ standard error.

\begin{tabular}{ccccc}
\hline & Estimate & SE & $t$-Value & $p$-Value \\
\hline Intercept & -6.6471 & 0.4087 & -16.27 & $<0.0001$ \\
Length & 0.0265 & 0.0032 & 8.27 & $<0.0001$ \\
Sex (Male) & 1.3720 & 0.5550 & 2.47 & 0.015 \\
Treatment (Starved) & 0.0474 & 0.0541 & 0.88 & 0.384 \\
Length $\times$ Sex (Male) & -0.0113 & 0.0044 & -2.57 & 0.012 \\
\hline
\end{tabular}


Table 3. Parameter estimates from the linear model of the brain-intestine index (BII), with statistical summary. SE = standard error.

\begin{tabular}{ccccc}
\hline & Estimate & SE & $t$-Value & $p$-Value \\
\hline Intercept & 1.1841 & 0.1712 & 6.92 & $<0.0001$ \\
Length & -0.0064 & 0.0013 & -4.81 & $<0.0001$ \\
Sex (Male) & -0.5864 & 0.2288 & -2.56 & 0.012 \\
Treatment (Starved) & -0.0080 & 0.0222 & -0.36 & 0.719 \\
Length $\times$ Sex (Male) & 0.0048 & 0.0018 & 2.66 & 0.009 \\
\hline
\end{tabular}

\subsection{Effects of Sex in Smolts}

No effects of sex were found in smolts in either relative size of brain (Length: $F_{1,14}=30.37$, $p<0.0001$; Sex: $F_{1,14}=2.05, p=0.17$; Sex $\times$ Length: $F_{1,14}=2.43, p=0.14$ ) or intestine (Length: $F_{1,14}=12.77, p=0.0031$; Sex: $F_{1,14}=1.03, p=0.33$; Sex $\times$ Length: $F_{1,14}=1.23, p=0.29$ ). Neither were any sex effects found when analysing BII (Length: $F_{1,14}=0.95, p=0.35$; Sex: $F_{1,14}=0.34$, $p=0.57$; Sex $\times$ Length: $F_{1,14}=0.40, p=0.54$ ). The general negative relationship between BII and body size was detected only when the interaction effect (Sex $\times$ Length) was removed from the model (slope estimate: $-0.0057 \pm 0.0015 \mathrm{SE} ;|t|=3.78, p=0.0018$ ).

\section{Discussion}

\subsection{No Long-Term Effects of Compensatory Growth on Brain or Gut Size}

Overall, the results suggest that there are no long-term effects of induced compensatory growth on brain or intestine size in juvenile brown trout. However, immediate effects of compensatory growth on energy allocation to brain and intestine growth remains to be tested experimentally, as it is still possible that brain and/or intestine growth is subnormal during the ongoing growth compensation period. Rios et al. [23] showed that the intestine length was reduced in starving wolf fish (Hoplias malabaricus (Bloch, 1794)) and it did not recover after refeeding, suggesting that the fish prioritized somatic growth over intestine regrowth. With respect to brain size, Devlin et al. [7] showed that faster growing growth-hormone transgenic coho salmon (Oncorhynchus kisutch (Walbaum, 1792)) had relatively smaller brains than non-transgenic individuals, suggesting that somatic growth was either prioritized under high growth-hormone expression, or at least partly uncoupled from brain growth. Hence, the immediate effects of compensatory growth on the growth rate of different organs is still worth investigating in future studies. However, here the conclusion is that the long-term effects are absent in wild brown trout.

\subsection{Emerging Sex Differences, Depending on Sex Bias Within Different Migration Strategies}

Sex is a factor contributing to the variation in brain size of juvenile brown trout. A previous study has shown that the relative size of the brain differs between anadromous migrants and stream residents, with the brain being larger in the residents [36]. In the present study, males and females had similar sized brains up to a size of approximately $130 \mathrm{~mm}$ in the study population. Given that the sampling was conducted in early spring on fish aged $2+$ years, the emergence of brain size differences between the sexes likely depends on smoltification. While most females become anadromous, a substantial proportion of the male population (a previous study indicate 34-57\%) stay as stream residents [39]. Male resident fish become mature in the parr stage (i.e., with the typical juvenile colouration) and never become anadromous [39]; eventually, at a larger size, they get the typical golden yellow colouration with black and red spots, characteristic of freshwater brown trout. In the experimental stream, male parr maturation is associated with a relatively high condition factor a year prior to maturation, and the size-range of maturing males covers most of the size-range that was observed in the present study ( $\approx 110-160 \mathrm{~mm}$ fork length) [40]. The apparent size-threshold for sex-specific divergence in brain and intestine size, at $\approx 130 \mathrm{~mm}$ fork length, could be explained by the tendency for larger $(\approx 130-170 \mathrm{~mm})$ 
juveniles to smoltify and migrate earlier in the season, typically in early April in the studied stream; smaller juveniles (down to $80 \mathrm{~mm}$ ) smoltify and migrate later in season, sometimes as late as June [41]. Anadromous individuals have also been shown to have a smaller relative brain size than stream residents [36], which supports this suggestion. Changes in the brain during smoltification has also been indicated in hatchery-reared Atlantic salmon, where the relative brain size decreases along with several physiological alterations [42]. It should also be noted that female residents have been shown to have larger brains than resident males [36], however this effect may not be visible in the data, as resident females are rare in the study stream [43].

During smoltification, the trout body gets elongated and slenderer [44]. If this morphological change is due to a relatively larger increment in body size relative to head size, it can explain the patterns that are seen. A relative increase in body length compared to the head could be associated with a relative increase in intestine length, and the brain growth may be restricted within the head. While there was no significant interaction effect between fork length and sex for head length, plotting of the data, supported by LOESS regression, suggested that the pattern is indeed similar to the brain data. Hence, the emerging change in body proportions during the smoltification process, which is initiated at least a couple of months prior to the migration [45], along with the sex-bias in smoltification rates [39], is considered to be a viable hypothesis for the emerging sex differences to be further tested in future studies.

While the results suggest that there are no detectable differences in brain size between the sexes in individuals smaller than $\approx 130 \mathrm{~mm}$, it should be noted that differences in specific brain substructures may still be present without affecting total brain size (see e.g., [30]). The lack of sex differences in total brain size in the smolts is in line with results from Atlantic salmon, where hatchery salmon pre-smolts (160-220 mm) were not showing any sex dependent differences in overall brain mass [46].

\subsection{Brain and Intestine Size: The Expensive-Tissue Hypothesis}

The brain-intestine index decreased substantially with fork length in females, however less so in males, although the same pattern was seen in the distribution of the data points (Figure 3C). This shows that the brain gets relatively smaller in relation to the intestine with size. Given that intestines often show a positive allometry [47], while brains have a negative allometry [7], the general pattern is expected. This pattern could potentially be a sign of the expensive-tissue trade-off, although not necessarily. Energy intake in trout moving seawards becomes important to achieve a rapid growth rate to be able to return to the natal river as a fecund or competitive individual [44,48]. Previous studies on other fish species have shown that rapidly growing species have relatively larger intestines [47]. As discussed above, since females tend to smoltify to a substantially higher degree [43], to adopt a marine fast-growth lifestyle, this may be the explanation for the differences in BII slopes between the sexes. Intestinal tissue is metabolically expensive [9] and it is possible that the reason for the smaller brains in relation to the intestine in larger trout is indeed an energy investment trade-off following the expensive tissue hypothesis. For instance, the requirement for a fast growth rate in the sea as post-smolt may have led to selection for a larger intestine during this life stage, which could potentially have been traded against relatively smaller brains. However, at this stage, one cannot exclude the possibility that the change in the relative size of the brain and intestine are not side-effects of other adaptive causes affecting for example, body versus head proportions, such as body shape hydrodynamics.

\section{Materials and Methods}

\subsection{Compensatory Growth: Effects on Relative Brain and Intestine Mass}

\subsubsection{Growth Manipulation}

The growth manipulation in this study has been described in detail in Näslund et al. [31]. In short, in spring 2010, 280 trout were captured in their natural stream habitat in south-western Sweden 
(stream Norumsån; WGS84: 58 $2^{\prime} 34.6^{\prime \prime} \mathrm{N} 11^{\circ} 50^{\prime} 45.0^{\prime \prime}$ E) and transported to the University of Gothenburg where they were tagged with passive integrated transponders (Trovan ID 100; Trovan Ltd., Melton, UK). Half of these fish $(n=140)$ were starved in the laboratory for one month while the other half $(n=140)$ were put back into their native environment; a strict control group maintained in the laboratory was considered unfeasible because it generally takes trout a substantial amount of time to acclimate and start feeding under laboratory conditions [49]. In the laboratory, the fish were group-housed in a 750-L tank (water temperature $12{ }^{\circ} \mathrm{C}$ ) that was enriched with plastic plants, and plastic-plates and -cylinders to provide hiding places. The starved fish were released back into their native stream after the starvation treatment. The fish were recaptured four times during the following year (see [31]). The summer growth pattern (as indicated by average specific growth rate, $G$ ) of the starved group indicated compensatory growth rates in mass (May to June: $G_{\text {controls }}=2.30, G_{\text {starved }}=2.65$; June to September: $G_{\text {controls }}=0.49$, $G_{\text {starved }}=0.54$ ) and length (June and September: $G_{\text {controls }}=0.18, G_{\text {starved }}=0.21$ ); no compensation occurred over winter (see Figure 1 in [31] for detailed visualisation in growth patterns). Out of 96 recaptured fish at the final recapture, 44 belonged to the control treatment and 52 to the starvation treatment; there was no significant difference in recapture rate between the treatments $\left(\chi^{2}=1.29, p=0.26\right)$. Analyses and figures from [31] are also freely available in [38].

\subsubsection{Tissue Sampling and Measurements}

On the final recapture (4 and 5 April 2011), all of the experimental fish were euthanized by an overdose of 2-phenoxyethanol $(0.5 \mathrm{~mL} \cdot \mathrm{L}-1)$, bagged individually, and brought to the University of Gothenburg for dissection. For preservation, we froze the fish whole until further handling was possible. Between 27 April and 2 May 2011, the fish were thawed and photographed using a digital single-lens reflex camera (house: EOS 40D; lens: EF-S IS USM 17-85 at 85 mm/f8.0; Canon Inc., Tokyo, Japan) which was mounted vertically on a table-top tripod. Thereafter, the fish were dissected; sex was determined by inspection of the gonads [50], the intestines (without the stomach, see Figure 4) were emptied from food-particles and were put in 95\% ethanol, and the heads were cut off behind the gill covers and put in $4 \%$ phosphate-buffered paraformaldehyde. In November 2012, the brains were dissected out of the heads, were put in $4 \%$ phosphate-buffered formaldehyde, and were stored in a refrigerator $\left(4{ }^{\circ} \mathrm{C}\right)$. The nerves were cut off as close to the brain as possible. Epiphysis and hypophysis were removed as these structures were not successfully retained from all of the specimens at the dissection (see Figure 4). The brainstem was cut as illustrated in Figure 4. In January 2014, the brains and intestines were blotted dry using filter paper and thereafter, they were dried for $43 \mathrm{~h}$ in $70^{\circ} \mathrm{C}$; after this, dry mass was weighed to the nearest $0.1 \mathrm{mg}$ (AB54-S, Mettler Toledo, Columbus, OH, USA).

To investigate the relative change in brain versus intestine mass, a brain-intestine index (BII) was calculated as:

$$
\mathrm{BII}=m_{\text {brain }} \cdot m_{\text {intestine }}^{-1}
$$

where $m_{\text {brain }}$ is the dry mass of the brain and $m_{\text {intestine }}$ is the dry mass of the intestine. Decreasing values of BII indicate that the relative size of the intestine increases compared to the brain.

Fork length (from the tip of the snout to the end of the central-most fin ray of the caudal fin) and head length (from the tip of the snout to the upper end of the gill slit) were measured from photographs using the software ImageJ 1.45r (W.S. Rasband, National Institutes of Health, Bethesda, MD, USA; http://imagej.nih.gov/ij/). 
A

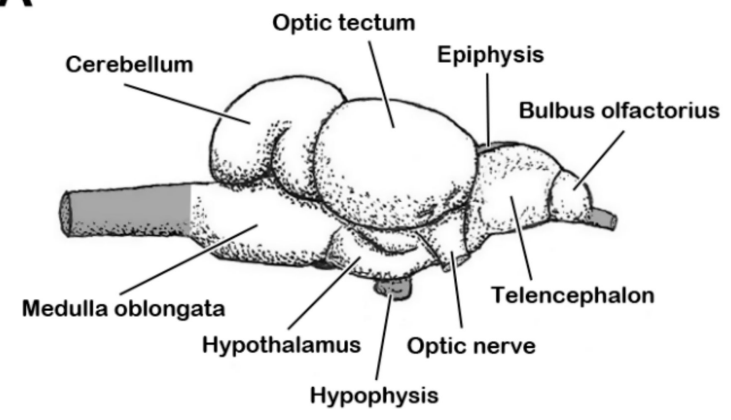

B

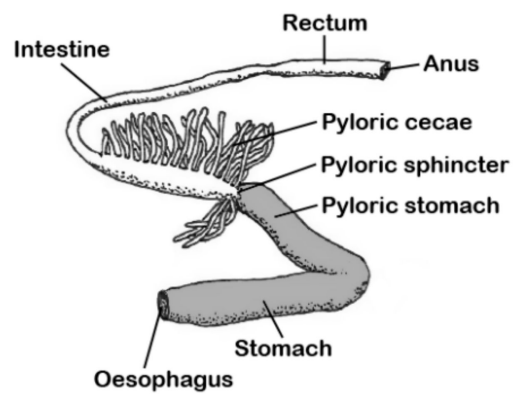

Figure 4. Illustrations of (A) the brain and (B) gut of brown trout. The brain was drawn from a photograph and was annotated after Meek \& Nieuwenhuis [51]; the gut was drawn and annotated after illustrations in Olsson [50] and Burnstock [52]. The grey shaded parts were not included in the measurements of mass.

\subsubsection{Data Notes and Comments}

Prior to analysis, one fish was removed from all analyses due to malformation of the body (spinal injury), leading it to be substantially shorter than what would be normal for its mass. A second fish was removed from the analyses involving brain size, since the brain was damaged during the dissection. A third fish was removed from the brain analysis, being regarded as an outlier due to its high brain dry mass (fork length: $120 \mathrm{~mm}$; brain mass: $0.0183 \mathrm{~g}(\ln (0.0183)=-4.00$; compare with data in Figure 2)).

Fork length was chosen as the size-representing covariate in analyses due to the fact that body mass varies substantially over relatively short time periods in salmonids. Mass is, for instance, associated with fat-reserves, which are variable in early spring (i.e., at sampling) depending on whether or not a given individual has started feeding at higher rates after the winter, during which growth is very restricted [31,53]. Fork length was judged to be a more representative measure of achieved growth in body size, since it is not affected by the energetic state at the time of sampling.

With respect to the smoltification status of the fish that were included in the growth manipulation experiment, this was not possible to classify from the collected specimens. The hypothesis of smoltification affecting brain size is derived from the current data set and the patterns that were observed were not anticipated. The collected fish were frozen prior to examination and the carcasses were discarded after dissections. Hence, assays to investigate physiological indicators of smoltification, such as cortisol or $\mathrm{Na}^{+}, \mathrm{K}^{+}$-ATPase [37] (used by e.g., $[45,54]$ ), were not possible to conduct. Furthermore, the assessment of silvering patterns (i.e., the accumulation of purines in the scales and superficial dermal layers of the skin [37]; used by e.g., [53,54]) from photographs were deemed unreliable for smolt-status assessment, partly due to the possibility that freezing would have affected the coloration, and partly due to the smoltification process being started prior to the silvering process.

\subsubsection{Statistical Analyses}

Fork length at the time of sampling was compared using a linear model including the factors Treatment (food restriction or no food manipulation) and Sex (male or female), and their interaction.

Brain and intestine dry mass, as well as head length, were analysed using linear models. Models for brain and intestine mass included the factors Treatment and Sex. Fork length ('Length') was added as a covariate and the interaction between Length and Sex was added to reveal any ontogenetic divergence in relative brain and intestine size between the sexes. For head length, treatment was excluded since this analysis was an ad hoc analysis to see whether head length followed the same pattern as brain size, and no indications of Treatment had been found in the brain analysis; the main focus of this analysis was the Length $\times$ Sex interaction. Differences were evaluated based on $p$-values 
that were derived from Type III analysis of variance, with $p<0.05$ being regarded as statistically significant. Tests were followed by graphical interpretation using LOESS with $95 \%$ confidence bands to capture non-linearity in the data.

\subsection{Investigating Sex Effects in Smoltified Individuals}

On 3 and 4 April 2014, additional samples of pre-smolts (i.e., silvered fish; males: $n=9$; females:

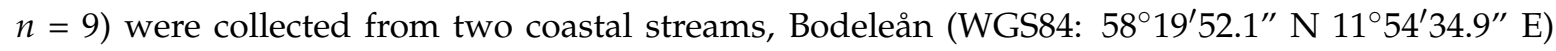

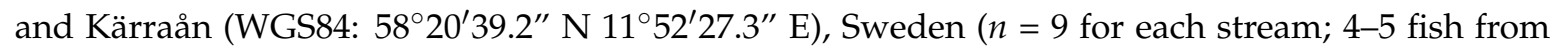
each sex). Body measurements and tissue sampling was conducted as above, except for tissues not being fixed in formaldehyde prior to drying. The BII for these fish were analysed using a linear model, including the independent variables, Sex and Length.

\subsection{General Notes and Ethical Compliance}

The experimenter was blind to the treatment during all of the measurements. Analyses and graphs were made in R 3.4.2 (R Core Team, R Foundation for Statistical Computing, Vienna, Austria). The experiment was conducted in accordance with Swedish law and regulations and was approved by the Ethical Committee on Animal Experiments in Gothenburg, Sweden (ethical permit 113-2008 and 26-2011).

\section{Conclusions}

This study showed that no long-term effects of compensatory growth could be detected on brain or intestine mass. Furthermore, sex differences in brain and intestine mass appear to be emerging over ontogeny, so that sex-differences at smaller stages $(<130 \mathrm{~mm})$ are not to be expected. However, when conducting comparative studies on organ size in salmonids at the time around smoltification, substantial effort should go into appropriately investigating body shape changes in relation to organ sizes. Finally, the current study suggests that the ontogenetic stage during which the salmonids smoltify might deserve more research efforts with respect to the energetic allocation to different tissues and the trade-offs involved.

Funding: Funding was provided by Wilhelm och Martina Lundgrens Vetenskapsfond.

Acknowledgments: Jörgen I. Johnsson, David Hammenstig, Caroline Blomgren, and Lin Sandquist are thanked for their assistance in the field and the lab during the main experiment. David Aldvén and Libor Závorka are thanked for their assistance in sampling the pre-smolts.

Conflicts of Interest: The author declares no conflict of interest. The funding agents had no role in the design of the study; in the collection, analyses, or interpretation of data; in the writing of the manuscript, or in the decision to publish the results.

\section{References}

1. Nijhout, H.F.; Emlen, D.J. Competition among body parts in the development and evolution of insect morphology. Proc. Natl. Acad. Sci. USA 1998, 95, 3685-3689. [CrossRef] [PubMed]

2. Dmitriew, C.M. The evolution of growth trajectories: What limits growth rate? Biol. Rev. 2011, 86, 97-116. [CrossRef] [PubMed]

3. Ali, M.; Nicieza, A.; Wootton, R.J. Compensatory growth in fishes: A response to growth depression. Fish Fish. 2003, 4, 147-190. [CrossRef]

4. Johnsson, J.I.; Bohlin, T. Compensatory growth for free? A field experiment on brown trout, Salmo trutta. Oikos 2005, 111, 31-38. [CrossRef]

5. Arendt, J.; Wilson, D.S.; Stark, E. Scale strength as a cost of rapid growth in sunfish. Oikos 2001, 93, 95-100. [CrossRef]

6. Arendt, J.D.; Wilson, D.S. Population differences in the onset of cranial ossification in pumpkinseed (Lepomis gibbosus), a potential cost of rapid growth. Can. J. Fish. Aquat. Sci. 2000, 57, 351-356. [CrossRef]

7. Devlin, R.H.; Vandersteen, W.E.; Uh, M.; Stevens, E.D. Genetically modified growth affects allometry of eye and brain in salmonids. Can. J. Zool. 2012, 90, 193-202. [CrossRef] 
8. Roff, D.A. An allocation model of growth and reproduction in fish. Can. J. Fish. Aquat. Sci. 1983, 40, $1395-1404$. [CrossRef]

9. Aiello, L.C.; Wheeler, P. The expensive-tissue hypothesis: The brain and the digestive system in human and primate evolution. Curr. Anthropol. 1995, 36, 199-221. [CrossRef]

10. Jensen, A.J. The "Gut index", a new parameter to measure the gross nutritional state of arctic char, Salvelinus alpinus (L.) and brown trout, Salmo trutta L. J. Fish Biol. 1980, 17, 741-747. [CrossRef]

11. Schmidt-Nielsen, K. Scaling: Why Is Animal Size so Important? Cambridge University Press: Cambridge, UK, 1984; ISBN 978-0521319874.

12. Rolfe, D.F.; Brown, G.C. Cellular energy utilization and molecular origin of standard metabolic rate in mammals. Physiol. Rev. 1997, 77, 731-758. [CrossRef] [PubMed]

13. Brijs, J.; Gräns, A.; Hjelmstedt, P.; Sandblom, E.; van Nuland, N.; Berg, C.; Axelsson, M. In vivo aerobic metabolism of the rainbow trout gut and the effects of an acute temperature increase and stress event. J. Exp. Biol. 2018, 221. [CrossRef] [PubMed]

14. Warren, D.L.; Iglesias, T.L. No evidence for the "expensive-tissue hypothesis" from an intraspecific study in a highly variable species. J. Evol. Biol. 2012, 25, 1226-1231. [CrossRef] [PubMed]

15. Kotrschal, A.; Rogell, B.; Bundsen, A.; Svensson, B.; Zajitschek, S.; Brännström, I.; Immler, S.; Maklakov, A.A.; Kolm, N. Artificial selection on relative brain size in the guppy reveals costs and benefits of evolving a larger brain. Curr. Biol. 2013, 23, 168-171. [CrossRef] [PubMed]

16. Liao, W.B.; Lou, S.L.; Zeng, Y.; Kotrschal, A. Large brains, small guts: The expensive tissue hypothesis supported within anurans. Am. Nat. 2016, 188, 693-700. [CrossRef] [PubMed]

17. Liu, J.; Zhou, C.Q.; Liao, W.B. Evidence for neither the compensation hypothesis nor the expensive-tissue hypothesis in Carassius auratus. Anim. Biol. 2014, 64, 177-187. [CrossRef]

18. Tsuboi, M.; Husby, A.; Kotrschal, A.; Hayward, A.; Büchel, S.; Zidar, J.; Løvlie, H.; Kolm, N. Comparative support for the expensive tissue hypothesis: Big brains are correlated with smaller gut and greater parental investment in Lake Tanganyika cichlids. Evolution 2015, 69, 190-200. [CrossRef] [PubMed]

19. Tsuboi, M.; Shoji, J.; Sogabe, A.; Ahnesjö, I.; Kolm, N. Within species support for the expensive tissue hypothesis: A negative association between brain size and visceral fat storage in females of the Pacific seaweed pipefish. Ecol. Evol. 2016, 6, 647-655. [CrossRef] [PubMed]

20. Zera, A.J.; Harshman, L.G. The physiology of life history trade-offs in animals. Annu. Rev. Ecol. Syst. 2001, 32, 95-126. [CrossRef]

21. Isler, K.; van Schaik, C.P. Metabolic costs of brain size evolution. Biol. Lett. 2006, 2, 557-560. [CrossRef] [PubMed]

22. Pankhurst, N.W.; Montgomery, J.C. Uncoupling of visual and somatic growth in the rainbow trout Oncorhynchus mykiss. Brain Behav. Evol. 1994, 44, 149-155. [CrossRef] [PubMed]

23. Rios, F.S.; Kalinin, A.L.; Fernandes, M.N.; Rantin, F.T. Changes in gut gross morphology of traíra, Hoplias malabaricus (Teleostei, Erythrinidae) during long-term starvation and after refeeding. Braz. J. Biol. 2004, 64, 683-689. [CrossRef] [PubMed]

24. Stevens, E.D.; Devlin, R.H. Gut size in GH-transgenic coho salmon is enhanced by both the GH transgene and increased food intake. J. Fish Biol. 2005, 66, 1633-1648. [CrossRef]

25. Wang, T.; Hung, C.C.Y.; Randall, D.J. The comparative physiology of food deprivation: From feast to famine. Annu. Rev. Physiol. 2006, 68, 223-251. [CrossRef] [PubMed]

26. Kotrschal, A.; Szidat, S.; Taborsky, B. Developmental plasticity of growth and digestive efficiency in dependence of early-life food availability. Funct. Ecol. 2014, 28, 878-885. [CrossRef] [PubMed]

27. Kotrschal, A.; Trombley, S.; Rogell, B.; Brannström, I.; Foconi, E.; Schmitz, M.; Kolm, N. The mating brain: Early maturing sneaker males maintain investment into the brain also under fast body growth in Atlantic salmon (Salmo salar). Evol. Ecol. 2014, 28, 1043-1055. [CrossRef] [PubMed]

28. Wiper, M.L.; Britton, S.; Higgs, D.M. Early experience and reproductive morph both affect brain morphology in adult male Chinook salmon (Oncorhynchus tshawytscha). Can. J. Fish. Aquat. Sci. 2014, 71, 1430-1436. [CrossRef]

29. Walsh, M.R.; Broyles, W.; Beston, S.M.; Munch, S.B. Predator-driven brain size evolution in natural populations of Trinidadian killifish (Rivulus hartii). Proc. R. Soc. B 2016, 283, 20161075. [CrossRef] [PubMed]

30. Näslund, J.; Larsen, M.H.; Thomassen, S.T.; Aarestrup, K.; Johnsson, J.I. Environment-dependent plasticity and ontogenetic changes in the brain of hatchery-reared Atlantic salmon. J. Zool. 2017, 301, 75-82. [CrossRef] 
31. Näslund, J.; Pauliny, A.; Blomqvist, D.; Johnsson, J.I. Telomere dynamics in wild brown trout: Effects of compensatory growth and early growth investment. Oecologia 2015, 177, 1221-1230. [CrossRef] [PubMed]

32. Park, P.J.; Bell, M.A. Variation of telencephalon morphology of the threespine stickleback (Gasterosteus aculeatus) in relation to inferred ecology. J. Evol. Biol. 2010, 23, 1261-1277. [CrossRef] [PubMed]

33. Costa, S.S.; Andrade, R.; Carneiro, L.A.; Gonçalves, E.J.; Kotrschal, K.; Oliveira, R.F. Sex differences in the dorsolateral telencephalon correlate with home range size in blenniid fish. Brain Behav. Evol. 2011, 77, 55-64. [CrossRef] [PubMed]

34. Kotrschal, A.; Räsänen, K.; Kristjánsson, B.K.; Senn, M.; Kolm, N. Extreme sexual brain size dimorphism in sticklebacks: A consequence of the cognitive challenges of sex and parenting? PLoS ONE 2012, 7, e30055. [CrossRef] [PubMed]

35. Schulz-Mirbach, T.; Eifert, C.; Riesch, R.; Farnworth, M.S.; Zimmer, C.; Bierbach, D.; Klaus, S.; Tobler, M.; Streit, B.; Indy, J.R.; et al. Toxic hydrogen sulphide shapes brain anatomy: A comparative study of sulphide-adapted ecotypes in the Poecilia mexicana complex. J. Zool. 2016, 300, 163-176. [CrossRef]

36. Kolm, N.; Gonzalez-Voyer, A.; Brelin, D.; Winberg, S. Evidence for small scale variation in the vertebrate brain: Mating strategy and sex affect brain size and structure in wild brown trout (Salmo trutta). J. Evol. Biol. 2009, 22, 2524-2531. [CrossRef] [PubMed]

37. Folmar, L.C.; Dickhoff, W.W. The parr-Smolt transformation (smoltification) and seawater adaptation in salmonids. Aquaculture 1980, 21, 1-37. [CrossRef]

38. Näslund, J. The Pace of Life of Brown Trout-Inter-and Intra-Individual Variation in Growth and Behaviour. Ph.D. Thesis, University of Gothenburg, Gothenburg, Sweden, 2015.

39. Dellefors, C.; Faremo, U. Early sexual maturation in males of wild sea trout, Salmo trutta L., inhibits smoltification. J. Fish Biol. 1988, 33, 741-749. [CrossRef]

40. Bohlin, T.; Dellefors, C.; Faremo, U. Probability of first sexual maturation of male parr in wild sea-run brown trout (Salmo trutta) depends on condition factor 1 yr in advance. Can. J. Fish. Aquat. Sci. 1994, 51, 1920-1926. [CrossRef]

41. Bohlin, T.; Dellefors, C.; Faremo, U. Date of smolt migration depends on body-size but not age in wild sea-run brown trout. J. Fish Biol. 1996, 49, 157-164. [CrossRef]

42. Ebbesson, L.O.E.; Braithwaite, V.A. Environmental effects on fish neural plasticity and cognition. J. Fish Biol. 2012, 81, 2151-2174. [CrossRef] [PubMed]

43. Pettersson, J.C.E. Incidence of Stream Resident Females in Anadromous Brown Trout (Salmo trutta L.) Populations in Small Streams on the Swedish West Coast. Ph.D. Thesis, Göteborg University, Gothenburg, Sweden, 2002.

44. Jonsson, B.; Jonsson, N. Ecology of Atlantic Salmon and Brown Trout. Habitat as a Template for Life Histories; Springer Science+Business Media, Inc.: Heidelberg, Germany, 2011; ISBN 978-94-007-1189-1.

45. Nielsen, C.; Aarestrup, K.; Nørum, U.; Madsen, S.S. Pre-migratory differentiation of wild brown trout into migrant and resident individuals. J. Fish Biol. 2003, 63, 1184-1196. [CrossRef]

46. Fraser, T.W.K.; Fjelldal, P.G.; Skjæraasen, J.E.; Hansen, T.; Mayer, I. Triploidy alters brain morphology in pre-smolt Atlantic salmon Salmo salar: Possible implications for behaviour. J. Fish Biol. 2012, 81, 2199-2212. [CrossRef] [PubMed]

47. Kramer, D.L.; Bryant, M.J. Intestine length in the fishes of a tropical stream: 1. Ontogenetic allometry. Environ. Biol. Fish. 1995, 42, 115-127. [CrossRef]

48. Aldvén, D.; Davidsen, J.G. Marine migrations of sea trout (Salmo trutta). In Sea Trout: Science E Management. Proceedings of the 2nd International Sea Trout Symposium; Harris, G., Ed.; Troubador Publishing Ltd./Matador: Leicester, UK, 2017; pp. 267-276. ISBN 9781788035354.

49. Johnsson, J.I.; Näslund, J. Studying behavioural variation in salmonids from an ecological perspective: Observations questions methodological considerations. Rev. Fish Biol. Fish. 2018, in press. [CrossRef]

50. Olsson, R. Kordatzoologi; Almqvist \& Wiksell: Stockholm, Sweden, 1971; ISBN 91-20-04499-2.

51. Meek, J.; Nieuwenhuys, R. Holosteans and teleosts. In The Central Nervous System of Vertebrates; Nieuwenhuys, R., ten Donkelaar, H.J., Nicholson, C., Eds.; Springer Verlag: Heidelberg, Germany, 1998; Volume 2, pp. 759-937.

52. Burnstock, G. The morphology of the gut of the brown trout (Salmo trutta). Q. J. Microsc. Sci. 1959, 100, $183-198$. 
53. Näslund, J.; Sundström, L.F.; Johnsson, J.I. Autumn food restriction reduces smoltification rate, but not over-winter survival, in juvenile brown trout Salmo trutta. Ecol. Freshw. Fish 2017, 26, 205-216. [CrossRef]

54. Rosengren, M.; Kvingedal, E.; Näslund, J.; Johnsson, J.I.; Sundell, K. Born to be wild: Effects of rearing density and environmental enrichment on stress, welfare, and smolt migration in hatchery-reared Atlantic salmon. Can. J. Fish. Aquat. Sci. 2017, 74, 396-405. [CrossRef] 